\title{
REGIONAL PECULIARITIES AND PRESENTATION FORMS OF TRADITIONAL (FOLK) AND MODERN URBAN CULTURE IN MARI EL REPUBLIC*
}

\author{
Nataya I. Efimova ${ }^{1 \star}$, Tatiana A. Zolotova ${ }^{2}$, Vera I. Toktarova ${ }^{3}$ \\ ${ }^{1}$ Ph.D, Mari State University, Russia, nordragon@mail.ru \\ 2 Prof., Dr., Mari State University, Russia, zolotova tatiana@mail.ru \\ ${ }^{3}$ Ph.D, Mari State University, Russia, toktarova@yandex.ru \\ ${ }^{*}$ Corresponding Author
}

\begin{abstract}
The paper offers characteristic features of regional peculiarities that the traditional and modern urban cultures of Mari El Republic possess. This region is remarkable for interaction of Slavic, Finno-Ugric and Turkic cultures. The authors display changes of the content and forms of Russian folk texts in XIX-XX (and $\mathrm{XXI}$ in the second part of the paper) as well as their propensity to borrowing. The material used in the study includes folk epic prose (stories, legends, bylichki) and poetry (historic songs, ballads and spiritual poems), ritual lyrical poetry (calendar rites and rites of the circle of life) and non-ritual lyrical poetry. As a result, the authors come to a conclusion that in the XX century in the Volga Region there were a number of events that proved detrimental for the traditional peasant way of life and culture. However, the analysis of the material manifests surprisingly well-preserved genres (among them there are genres common for the Russian culture of the Volga Region) as well as separate unique species, their vitality and power. It is important to notice that the most talented performers of folk pieces, their family members and their community seem to have preserved a highly respectful attitude towards traditional values, faith in their effectiveness, a desire to share their knowledge. To the most significant constituents of their life experience one can refer an ability to live in harmony, to give a helping hand when needed, to worship nature, to be conscientious, sympathetic, and socially optimistic despite hard lives. As for the artistic value of Russian folklore of Mari El Republic, the condition of texts recorded in the area proves the opinion of researchers working outside the republic. Nowadays works of folk-art that fulfil educational, informative and communicative functions take the first place. In most cases the mythological basis has been lost. As a result, many of ritual forms have become games. Almost all genres demonstrate the process of their semantic update. Old forms are filled with new content. The traditional imagery has simplified a lot; a number of artistic devices, which are not of current interest, have been lost. In the field of ethnic interactions, one should pay attention to the tauseneviy door-todoor rite, which is unique in its archaic basis and verbal accompaniment. The rite emerged at the junction of Finno-Ugric (the Mordva) and Slavic (the Russians) ritual culture. The paper also introduces forms of modern presentation of regional folklore and shares the authors' experience of developing virtual folklore museums with game play elements. The last part of the paper deals with the phenomenon of the Internet folklore of
\end{abstract}

\footnotetext{
* The reported study was funded by RFBR and Government of the Mari El region according to the research project № 16-
} 14-12005 and 16-04-12003. 
Mari El Republic. The Internet and specific public pages in social media have been serving a platform for contemporary folklore focusing on urban culture and people's perception of urban realia for almost a decade. The paper covers the Internet genres of folklore and their functions including their role of markers of local identity, and street art as a reflection of certain tendencies of a town's life.

Keywords: Russian folklore, regional folklore, genres, ethnocultural interaction, rites, virtual museum, Internet folklore

\section{INTRODUCTION}

Modern folklorists include the Volga region in the group of regions characterized by the "increased intensity of folklore contacts" (Putilov, 1983, p. 10); they call it "the greatest laboratory <of multifold historico-poetical movements and> processes" (Gatsak, 1983, p. 5). Of particular interest is the culture of the local centers in which Slavic and Finno-Ugric elements interact directly (the so-called "limitrophe areas" - border districts and the regions with mixed Slavic and Finno-Ugric population). Several loci of Mari El Republic can be considered among the areas of this type (Zolotova ,1997). The contacts between the Russians and the Mari within these areas are usually characterized as interactions between "the neighboring peoples culturally close to each other" (Kostiukhin, 1993, p. 8). As a rule, these contacts are lengthy and continuous. In some cases, certain stages can be singled out in such relations: the initial stage is connected with the formation of stable forms of cultural interaction, while the nature of the relatively subsequent stage is defined by secondary influences.

In this article, the modern forms of traditional Russian folklore are presented. The folklore material was gathered during the expeditions carried out by the students and the instructors of Mari State University (MarSU) in the territory of Mari El Republic in the 1970s and 1980s. The second records were made in 20122016.

\section{METHODS}

In the process of gathering, systematization and analysis of the material we used such methods and particular procedures as interviewing, participant observation, comparative-historical and typological methods.

\section{RESEARCH}

\subsection{Epic poetry and prose}

Epic poetry includes historic songs, ballads and spiritual poems. Historic songs draw the folklore researchers' attention in the first place. With good reason, V. K. Sokolova wrote about the "abundance and variety of historic songs in the Middle Volga Region". According to her, this is where "almost all the known (historic - T. Z.) plots were recorded" (Sokolova, 1960, 318)]. Indeed, along with the plots explaining the important events from the history of this area ("Vziatie Kazani" ("The Taking of Kazan"), "Molodets zovet devushku v Kazan" ("A Young Man Invites a Maiden to Kazan")), the wide-spread occurrence of the cultural works unrelated to the area directly is also stated by the participants of the MarSU expeditions. Among them, there are songs about the Russian-Swedish conflict of 1788 ("Eshche li ia korol' shvedskii..." ("I am the Swedish King..."), 15 variations), the French invasion of Moscow in September 1812 ("Napoleon v Moskve" ("Napoleon in Moscow", 5 variations)), the death of Alexander I ("Smert' Aleksandra I v Taganroge" ("The Death of Alexander I in Taganrog"), 7 variations), the Russo-Turkish War of 1828-1829 ("Turetskie ugrozy" ("Turkish Threats"), 4 variations) and some others. These songs strongly illustrate the way singers "adapt" historical facts. In a popular historic song "Napoleon in Moscow" a collective image of the enemy ("the wicked French", "the thief", "the robber") is replaced by the image of Napoleon (<he> "walked with a gun along the river" and "fired a one-pood ball"). At the same time, the "devastator" of Moscow possesses the attributes of a nice young man (!). Additional research shows that this tendency is typical for the songs in this area (Zolotova, Selezneva, 1996, p. 34-38). In the process of the creation of a historic text singers were turning to the lyric plots well-known in the Volga region. In this case, a popular lyric scheme is also used to reconstruct one of the crucial moments of the Patriotic War of 1812: "an evil man has ravaged the village for a trifle / a fair maiden" (Ibid., p. 37).

Among epic works in prose, legends, toponymic stories (traditions) and bylichki stand out. 
Unfortunately, the first records of the works reflecting spiritual and religious conceptions were created in Mari El Republic only in the last decades of the 20th century in the context of the common interest of folklorists in legend and its varieties. In Mari El Republic, these works reflect the phenomenon of the so-called "folk Orthodoxy", and it is not coincidental. On the one hand, there are quite notable centers of Orthodoxy (monasteries, well-known parishes) in the republic; on the other hand, the practices of setting up vow crosses, worshiping of springs and certain tree species are wide-spread in this territory, as well. The Russian peasants have also been known to visit the Mari pagan places of worship.. M.V. Svinina (Kuzhenersky District) told: "A Russian muzhik <peasant> went (to the prayer area) near Tun'iumuchash. Came there. And there are the fires burning, the soup is being cooked. They say, if Russian comes to Mari, it brings luck. In fact, if Mari has a Russian guest, a good fortune will visit his house. On Semik, people went to pray to Vizimbir'. To Paganur. All of them: both Russians and Mari. Well, Russians and Mari share the same faith".

The remarkable topics of legends include the plots about monastery founders and the beginning of construction of church buildings. Interesting that it's usually indigenous inhabitants who initiate the erection of several churches. "...after Toktai the pagan had converted to Christianity, he built a wooden church and named it Il'inskaia" (A. P. Vershinina, Kuzhenersky District).

The legends about closure and demolition of monasteries and churches during Soviet rule are also widespread. These works relate to sacrilegious attitude to sacred objects and places and to the usually dreadful subsequent retribution for the sins against faith and Church.

The most wide-spread variety of traditions is toponymic. The analysis of these stories shows that the names of settlements given by Russian inhabitants were based on the long-standing cultural norms of the region. Newly formed settlements were usually named after the first names/family names or, less frequently, ethnic identity of the first inhabitants (Akulovo, Gubino, Lebedevo, Petrovo etc.). The names of some villages were based on the local landscape features (Bolotnaia (Marshy), Malaia Gora (Small Mountain), Chernyi Kliuch (Black Spring), Osinovyi Kliuch (Aspen Spring), Bolotnyi Kliuch (Marshy Spring), Dubrovka (Oak Wood) etc.). The names of a number of villages are based on their inhabitants' behavior features: both positive and negative (Korosteli (Landrails), Tarakanovo (Cockroaches), Ershi (Ruffs), Laptevo (Bast Shoes) etc.). Another remarkable tradition is to add an ethnic marker to an already existing geographical name (in the case of a substantial change in the composition of the population) (Russkaia Mosara (Russian Mosara), Russkie Shoi (Russian Shoi) etc.).

The stories about encounters with the creatures from the other world are still popular in the Mari part of the Volga region. The bylichki (true stories) about all kinds of Slavic mythological characters (Leshy (a forest spirit), Vodyanoy (a male water spirit), Rusalka (a female water spirit), Dvorovoy (a spirit of the courtyard), Ovinnik (a spirit of the threshing house), Bannik (a bathhouse spirit), Poludnitsa (a noon spirit), Shishiga (a female swamp or forest creature), Chort (a horned and hoofed demon), witches, cursed people etc.) are recorded in this area. The stories about Domovoy (a house spirit) are especially popular. The bylichki about Ognennyi (a fire spirit) can be considered regionally particular. All the basic genre peculiarities are preserved in these texts: firstly, these stories concern not only unusual, but also inexplicable and frightful events; secondly, they are presented as an "evidence", and therefore the narration is presented from the perspective of a so-called "eyewitness" of the events; and finally, the climax of the story starts with an adverb "suddenly". Other significant features of mythological stories in this area include the tragic nature of denouement, the mysterious nature of chronotope and ominous overall atmosphere.

\subsection{Calendar rites and folklore}

The works of ritual poetry are of a certain scientific value. The MarSU archive contains detailed the descriptions of calendar rites, along with the texts of koledari, tausen, Maslenitsa (Butter Week) and Troitsa (Trinity) songs, stroll and round songs, as well as the descriptions of actions performed during the singing.

It is impossible to comment on every rite in this article, however we find it necessary to mention those more peculiar and unique from the perspective of their artistic specificity or the conditions of their existence in this area.

The folk calendar begins with Christmas rites, just as in all the other regions of Russia. In Mari El these rites include door-to-door rounds, mummers plays, fortune-telling and Christmas-tide evenings. The door-to-door rounds were initially formed in this area in their tausen variety (Zolotova, 1997).

It can be assumed that the tausen door-to-door rounds are genetically connected with the rituals of sending the souls of the deceased off. Such rituals are quite complicated and still practiced among the Mari and the Mordvins living in this region. The similarities in the New Year and funeral rites (the aspect of protection of the living from possible harmful influence of the dead) are also interesting in this context. The ritual elements 
aimed at obtaining this protection include the prayer songs (their central motive consists in asking the ancestors to "guard the living"), the ritual meal (characterized by the presence of "common" dishes, special ways of "feeding the souls" and the idea of various forms of the connection of the latter with the humans' places of living), actions with ashes, straw and rubbish (their removal from the territory of the living), the more significant, as compared with the Christmas rituals, meaning of water (the departure of the dead into the other world by water), the shift in the meaning of fire (it "warms the souls" on Christmas, but "lights the way/the return" on New Year's Day). A new meaning of the symbols, which are also used on Christmas, is also remarkable: the "pig head", for instance, is devoid of the sacred idea of the subsidiary vital energy; the ancestral relics (such as the Mordvinian "candle of ancestors") are also excluded from the ritual.

The personal code of the ceremony undergoes certain changes, as well: its new main characters are older children of the family and elderly women.

The folklore works included into the rite of tausen door-to-door round reveal interesting changes in their genre and plot variety, as well as structure and poetic style. For example, song requests for treat and cumulative songs can be attributed to the tausen songs of Russians in the Volga region and Mari El Republic. As for the praising songs, they represent a Slavic variety of the tausen cycle and stand out for the presence of the motive of wedding praises and advanced binomial structure.

It should also be noted that the archaic details in Russian tausen songs are already spread over various plots. They are connected with the deep meaning of rite (the type of the ritual food, the ritual characters, the idea of the interdependency of the treat and the bumper harvest etc.) and in some cases can serve as the "building blocks" for the new works. These details are prone to various "augmentations", "enrichment" etc.

\subsection{Rites of the circle of life}

Among domestic family rites, the traditions and ceremonies connected with wedding and delivery prevail.

An attempt to reconstruct the Russian birth rite in Mari El Republic is already made in the monograph "Birth Rite in Vyatka: Descriptive Models" (Zolotova, 2004). The authors conclude that the ethnographic component of the rite consists of the pre-birth cycle, the birth itself and the post-birth cycle. However, the actual contents of each stage (the ritual actions within a cycle and their interrelation) reveal some regional peculiarities.

Thus, in order to define the gender of the coming child during the pre-birth cycle, along with some methods widely known in Russia, dish songs ("ileia") were used. Some of them could "predict" not only the child's gender, but also the total number of children and even extramarital pregnancy.

The structure of delivery was defined by the actions aimed at its easing, "completing" the infant's body, identifying his nature, giving him strength and providing him with gifts. The delivery was accompanied by a large number of incantations. The most popular texts were aimed at easing the process of delivery, preventing the screaming and protecting from hernia. The latter type of incantations is characterized by a number of regionally specific features. There are several variations of the incantations against hernia: "epic" versions with the traditional structural elements ("A gnawing hag went not in the air, not along the road, not around the swamp..."); two-fold structures with an archaic magic formula "as..., so..." ("As the stone stands still, so the Lord's servant <name> may be still...") or one-fold structures with the motive of biting ("Here, hernia, here's your ramp, go to the ceiling, bite a plank there, and don't touch the baby <name>"). The magic of numbers (partly borrowed from the native inhabitants of the region), repetitions and enumerations are used in this group of incantations.

During the postnatal period, the main rites were devoted to purification and health of the mother and her child, as well as to their inclusion in the society. Initially, the main characters of these rites were the midwife and the mother. This fact is evidenced by a ceremony of the mother's feeding. This rite is wide-spread in the region. The incantations against hex, rodimets (eclampsia), fright and perepolokh (panic) can be considered as a special kind of protection within this period.

The child's inclusion in the society is connected in the local peoples' consciousness with the ceremonies of christening and name-giving. In general they were carried out in accordance with the traditions of the Orthodox Church. However, the performers' interpretations of these ceremonies were definitely influenced by the folk Orthodoxy and the traditions of the Old Believers.

With regard to the Russian wedding ceremony in Mari El Republic, it can be called a truly unique phenomenon of the traditional culture of the Volga region. Such conclusions can be made on the basis of numerous ethnographic descriptions, different kinds of evidence and well-preserved folklore texts.

The researchers of the Russian folklore in Mari El Republic have discovered two models of the wedding ceremony: Yurinsky wedding and Vyatsky wedding (Zolotova, 1991; Zolotova, 2001). Each model possesses 
its own peculiar features.

The first type - Yurinsky wedding - is recorded on the left bank of the Volga (at the place of its confluence with the Vetluga). It is kindred to the domestic family rite complex of the Volga region and characterized by the detailed schemes of hen night and the wedding day morning. Ceremony experts consider these elements to be independent structural components. The ceremony of a farewell to beauty was considered to be the main rite of the pre-wedding week in the Yurinsky District of Mari El Republic. The bride, surrounded by her immediate relatives and friends, was saying goodbye to her girlhood and its freedom. The bride's key action in this ceremony was to take off her head-dress (a beaded ribbon) and pass it to her younger sister or best friend. Other obligatory actions included unplaiting and combing the bride's hair. After that, the hair was plaited again; it was the last time the bride had her hair plaited in a girly manner. In the morning of the wedding day a ceremony of "leading the bride to the tables" was performed. It involved many actions and texts (the bride's address to each relative, the redemption of a seat beside the bride, the "bidding" for the bride's plait, blessing at the altar etc.).

This type of wedding is also characterized by the epic tradition of lamentation and the bride's ritual behavior within its scope. In particular, the bride tells about the actions to be fulfilled by means of the ritual texts. For instance, in the morning of the wedding day she uses special lamentations to ask the others to help her wash herself ("Oh, my darling mummy // Oh, a poor orphan that I am, I cannot sleep..."), to retell her prophetic dream ("Oh, my dear friends // I cannot sleep in this dark night..."), to send a dowry into the bridegroom's house ("Oh, I shall bore you, my darling brother..."), asks for the blessing ("Look, you breadwinner, father, // Look who stands here in front of you..."). Some lamentations can be considered as remarkable pieces of wedding lyrical poetry ("Look, you breadwinner, father..." and others).

\subsection{Non-ritual lyrical poetry}

The section of non-ritual lyrical poetry is quite extensive. It includes lyrical songs, folk romances, songs of a literary origin, chastooshkas (two-or four-line humorous ditties). Musicologists recorded both long lyrical and fast songs (the local people call them "lengthwise" and "rapid", respectively). The Russian soul is actually reflected in these works, with all its courage and patience, daring and grief that makes the heart ache, sincere tenderness for father and mother, wife and young children; for "every small bush, every twig and every hillock" of the homeland. Some of these songs are well-known in the central part of Russia. But many others - such as "Blow, blow, you weather of the lowland...", "My mother scolded me...", "The storm-cloud comes not at night...", "Mother, stop the grief...", "I lay in the road, destitute..." etc. - will bring joy to the hearts of both an expert on folklore and a person who discovers the Russian singing traditions for the first time. Several labor songs were recorded in the Yurinsky district. According to E. S. Merkur'eva, the song "Oh don't wake the young // Early in the morning...", for instance, was sung in the village of Kozikovo while removing timber: "They loaded timber, bound it with tsinok (a special twisted wire - T. Z.) and pulled the chain. Worked in groups of 12 persons". The refrain is a key segment of the song; it regulates the working process: "Moves- it moves, in leads, in motions, oh it moves, it leads, in motions". Chastooshkas were also sung in this region in the same way as labor songs or lullabies.

\subsection{Data on the housing, interior house decoration and folk costumes}

The participants of the expedition led by $\mathrm{N}$. Bol'shova also recorded the information on the erection of villages, architecture and interior house decoration, traditional clothing and footwear.

The Russian villages are characterized by either street (in smaller settlements) or street-block (in bigger settlements) planning. Manors usually have rectangular shape; they are connected with outbuildings through double-row L-shaped passages. The performers repeatedly stressed that the most popular types of buildings in the 1920s-1930s were izbas with log extensions and 5-walled houses. Nowadays instead of klets (timbered shacks) they build spacious inner porches with store-rooms. A separable type of the dwelling (izba + inner porches) is especially wide-spread.

The interior of the house demonstrates the prevalence of North Russian traditions: a Russian stove is situated in the corner by the door; its orifice faces the windows to the outside. Diagonally across the room, there is a place of honor ("the red corner", a worship space). The kitchen (sered, i. e. "middle") is separated from the living quarters by a partition. In many dwellings a polati (a stove-bench) is set up; less often its role is played by a golubets (a platform by the stove). The planning according to which the orifice of the stove faces a blank wall is also known.

The exterior decoration of the buildings reveals the traces of Finno-Ugric influence. People decorate their houses with excised carving decoration with geometric patterns; plant trees, hop and other plants around manors etc. 
In the 19th century, the wide-spread women's clothing set consisted of a long shirt worn on a naked body, a straight ("round", "Moscow") sarafan (a long sleeveless gown), a zapon (an apron) and a belt. Men wore long homespun shirts with straight sleeves without cuffs, and with an embroidery on the chest. Young men preferred shirts with cuffs and pripolok (a patch with buttons). The collar and the pripolok were embroidered. According to the performers, these old clothes (sarafans, embroidered shirts, chekhlushkas - women's head-dress) gradually lost their everyday nature and obtained festive and ritual meaning. In the first decades of the 20th century, a costume became fashionable. A woman's costume consisted of a skirt and a jacket. Skirts with a "tail" (i.e. the cloth on the back of the skirt was much longer than the frontal side) and "closed" jackets with buttons, a stand-up collar and puffy sleeves were especially popular. The rich had their costumes made of purchased factory-made drapery; wool dresses in the "urban" style and basque jackets were more wide-spread. Men wore boots, while women preferred lace-up shoes (Bol'shova, Vishniakova, Zolotova, Ivanova, 2000).

\subsection{Forms of presentation of the folklore of Mari El Republic}

The folklore of Mari El Republic is represented in the form of two virtual museums.

The Virtual Folklore Museum of Yurinsky District. This type of electronic database is based on the principle of an excursion with the elements of a game. Its most peculiar feature is interactivity: the user becomes a full-fledged participant of the interaction with the virtual environment of the museum. The virtual museum is "situated" in famous Sheremetiev Castle from the Yurinsky district of the republic (on the left bank of the Volga, near the place of its confluence with the Vetluga). Of 100 rooms of the Castle, the museum"takes" only 5. Besides, only the front entrance and the splendid staircase leading to the central part of the castle are left unchanged; the other 4 rooms were turned into a new reality. The hall of the "Historic Songs", for instance, houses a collection of portraits of significant historical figures. If the user clicks on a portrait, he will get acquainted with the description devoted to the person represented. In the hall of the "Ritual Folklore", the collections of national toys are presented (primarily, Dymkovo toys). By clicking on the figurines of the bride and the groom, the user gets an access to the description of the wedding folklore, while the click on the procession of characters provides the information on the calendar holidays. Various types of garmons (harmonicas) in the next hall keep numerous types of chastooshkas. If the user clicks on the image of the old-fashioned gramophone which appears in the bottom right corner of the screen in every hall, he will be able to get acquainted with the best examples of historic songs, long lyrical songs connected with wedding ceremonies, wedding songs (including the bride's lamentations), as well as round dance and playing songs connected with the Trinity-Semik holiday cycle. The songs are performed by the folk ensemble "Tsarev gorod" ("Tsar City") (the director is Maria Valentinovna Busygina). All the halls of the museum are consolidated into a single excursion. The role of the guide is played by one of the famous characters connected with the new look of the city of Yoshkar-Ola - "Yoshkin kot" ("The Cat of Yoshka"; there's a statue of him sitting on the bench near the entrance to the main building of MarSU). In the virtual museum this Cat comes alive in a 3-dimensional visualization; he gets off the bench (in the reality of the museum the latter is situated near the entrance to Sheremetiev Castle) and approaches the viewer. Being a truly folklore and mythological creature, the Cat starts with an introductory monologue; the entrance to every hall is preceded by his commentaries. They give a very laconic, but, at the same time, accurate characteristic of every collection and also point out the most outstanding features, which may be considered remarkable by a not well-informed visitor. The project also includes the elements of a game. The viewer - who turns here into a user or a player - cannot enter the "other world" of Sheremetiev Castle right away. First he should find the "key": the artifacts connected with the history, landmarks and domestic life of the Yurinsky district. These artifacts are hidden in a trunk opposite the Cat's bench. As a reference, the creators of the databased used the ideas of the "hidden object adventure" computer games. The user finds the items with the help of a hint (at the bottom of the trunk). He should click on every item mentioned in the hint, and if an item has something to do with the folklore, culture and history of the Yurinsky district, its description and historical reality appear at the top of the screen (Zolotova, 2016).

The Virtual Folklore Museum of Gornomariysky District. This database is created in the form of a website. It includes a number of collections interconnected with each other with the hyperlinks. The central locus of the site is a painting of a famous Mari artist and the Honored Cultural Worker of the Russian Federation I. V. Efimov "Towards the Native Shore". Its content is revealed and extended with the help of the collections devoted to the topic "Fishery" (photos, artifacts, myths, interviews). The links to the collections can be found below the painting. The elements of animated cartoon are used in the styling of the painting (Zolotova, 2016). 


\subsection{New forms of folklore in Mari El Republic}

The traditional folklore in Mari El Republic, though still preserved, highly estimated and researched by scholars, is giving way to new forms that, undoubtedly, have much to do with traditional criteria of folklore such as variability, anonymity, traditionalism, oral character, collective character and syncretism. These new forms are genres of the Internet-folklore. To them we refer memes, demotivators, and gifs. Young people living in towns of Mari El Republic create a lot of works of this kind. As a rule, they are hosted by social media on particular public pages devoted to a city's life and are studied as local texts proclaiming symbols of local identity (Efimova, Zolotova 2017). In the capital of Mari El Republic, the town of Yoshkar-Ola, there are a number of images and themes existing that serve as markers of local identity and, therefore, memes of the given town: the sculpture of the Cat of Yoshka, Yoshkar-Ola Hotel, the ex-governor, the idea of bad roads, etc. Another form of young people's self-expression is street art that has also become a part of the Internet image of the town as street artists have found a possibility to preserve their works of art in the Internet.

\section{CONCLUSION}

The events of the 20th century were in many respects destructive for the traditional peasant way of life and the traditional culture connected with it. However, the analysis of the materials reveals astoundingly good preservation of the considerable number of genres (including the ones which are widely recognized in the Russian culture of the Volga region), as well as of individual traditional works, which turn out to be quite viable and influential. It's important to highlight the fact that the most talented performers (A. K. Ermicheva, E. S. Merkur'eva, I. V. Rakushin, E. E. Simonova, N. P. Mikheeva and others), as well as the members of their families and their immediate circle, have preserved respectful attitude toward the traditional values, the assurance of the force of these values and the striving for sharing this knowledge with others. Among the most important components of their personal and social experience, we can distinguish the ability to live in peace and harmony with themselves and others; the hospitality for people; respect for nature and especially for "the Volga Mother"; conscientiousness, tenderness, delicacy and, despite the complicated destinies, social optimism.

As for the artistic value of the works of the Russian folklore in Mari El Republic, the condition of the texts recorded in this region reaffirms the conclusions of the researchers studying the classic folklore in other regions of Russia. The orientation of genres has changed: the works performing cognitive, informative and communicative functions are now brought to the forefront. The mythological background of the actions is lost in most cases, which results the shift of many ritual forms into the category of the playing practices. The process of semantic renewal is remarkable practically in all the genres: the old forms obtain the new matter. The traditional figurativeness has noticeably simplified; the artistic methods, which turned out to be irrelevant nowadays for any reason, were lost.

It is also important to note that the available folklore materials are being actively used: on their basis the virtual folklore museums of the Yurinsky and the Gornomariysky Districts are created. Another project based on these materials is an experimental research of the Federal Institute of Education Development (Moscow) in the Mari El Republic aimed to create a system of spiritual and moral upbringing of the younger schoolchildren within the framework of a federal web-based resource. The Internet does not serve as a means of preserving and displaying the traditional folklore only. It has become a platform of new forms of folklore revealing young people's attitudes to the place they live in.

\section{REFERENCE LIST}

Bol'shova, N., Vishniakova, N., Zolotova, T., Ivanova, L. (2000). Sovremennoe sostoianie russkoi traditsionnoi kul'tury Respubliki Marii El [Modern Condition of Russian Traditional Culture in Mari El Republic]. Yoshkar-Ola: Mari State University, 2000. 96 p.

Efimova, N., Zolotova, T. (2017). Local text of a provincial town in Internet-folklore. International e-Journal of Advances in Social Sciences. Vol.3, issue: 7, April, 2017, pp.113-116.

Gatsak, V. M. (1982). O perspektivakh izucheniia mezhnatsional'nykh fol'klornykh obshchnostei i vzaimosviazei [On the Perspectives of Study of International Folklore Communities and Interrelations]. Mezhetnicheskie obshchnosti i vzaimosviazi fol'klora narodov Povolzh'ia i Urala [Interethnic 
Communities and Interrelations in the Folklore of the People of the Volga Region and the Urals] (The proceedings of the symposium, 22-24 November 1979). Kazan: The Academy of Sciences of the USSR (The Department of Language and Literature, Kazan branch), 1983. P. 3-7.

Kostiukhin, E. A. (1993). Skazki i tipologiia kul'turnykh kontaktov [Fairy Tales and the Typology of Cultural Contacts]. Russkii fol'klor. T. 27: Mezhetnicheskie fol'klornye sviazi [Russian Folklore. Vol. 27: Interethnic Folklore Relations]. Saint Petersburg: Nauka, 1993. P. 3-14.

Putilov, B. N. (1983) K tipologii mezhetnicheskikh fol'klornykh sviazei: priroda, zakonomernost', mekhanizm [On the Typology of Interethnic Folklore Relations: Nature, Pattern, Mechanism]. Mezhetnicheskie obshchnosti i vzaimosviazi fol'klora narodov Povolzh'ia i Urala [Interethnic Communities and Interrelations in the Folklore of the People of the Volga Region and the Urals] (The proceedings of the symposium, 22-24 November 1979). Kazan: The Academy of Sciences of the USSR (The Department of Language and Literature, Kazan branch), 1983. P. 7-13.

Sokolova, V. K. (1960) Russkie istoricheskie pesni XVI-XVIII vekov [Russian Historic Songs of 16-18 Centuries]. Moscow: Nauka, 1960. 326 p.

Zolotova, T. A. (1991) Russkaia svad'ba (russkaia svad'ba lurinskogo raiona Mariiskoi ASRR) [Russian Wedding (Russian Wedding in Yurinsky District of Mari ASSR)]. Yoshkar-Ola: Republican polygraphic editorial association of MASSR Goskomizdat, 1991. 44 p.

Zolotova, T. A. (1997) Tausenevye pesni russkih Povolzh'ja: regional'noe svoeobrazie i mezhjetnicheskie svjazi [Tausen' Songs of the Russian People in the Volga Region: Local Originality and Interethnic Relations]: doctoral thesis in philology: 10.01.09. Yoshkar-Ola, 1997. 342 p.

Zolotova, T. A. (2016) Virtual'nyi muzei fol'klora lurinskogo raiona RME: Elektronnyi obrazovatel'nyi resurs [The Virtual Folklore Museum of Yurinsky District of Mari El Republic: Electronic Educational Resource]. Yoshkar-Ola, 2016. URL: http://vmuseum2.marsu.ru/

Zolotova, T. A., Ivanova, A. A., Shestakova, I. N. (2001) Viatskaia svad'ba [Wedding in Vyatka]. YoshkarOla: Mari State University. 2001. 96 p.

Zolotova, T. A., Ivanova, E. S. Viatskii rodil'nyi obriad: modeli opisaniia [Birth Rite in Vyatka: Descriptive Models]. Yoshkar-Ola: Mari State University, 2004. 104 p.

Zolotova, T. A., Plotnikova, E. A., Toktarova, V. I. (2016) Virtual'nyi muzei fol'klora Gornomariiskogo raiona: Elektronnyi obrazovatel'nyi resurs [The Virtual Folklore Museum of Gornomariysky District: Electronic Educational Resource]. Yoshkar-Ola, 2016. http://vmuseum.marsu.ru/

Zolotova, T. A., Selezneva N. A. (1996) Napoleon v Moskve [Napoleon in Moscow] /Arkheograficheskii vestnik [Archaeographic Bulletin], No. 6. P. 34-38. 